
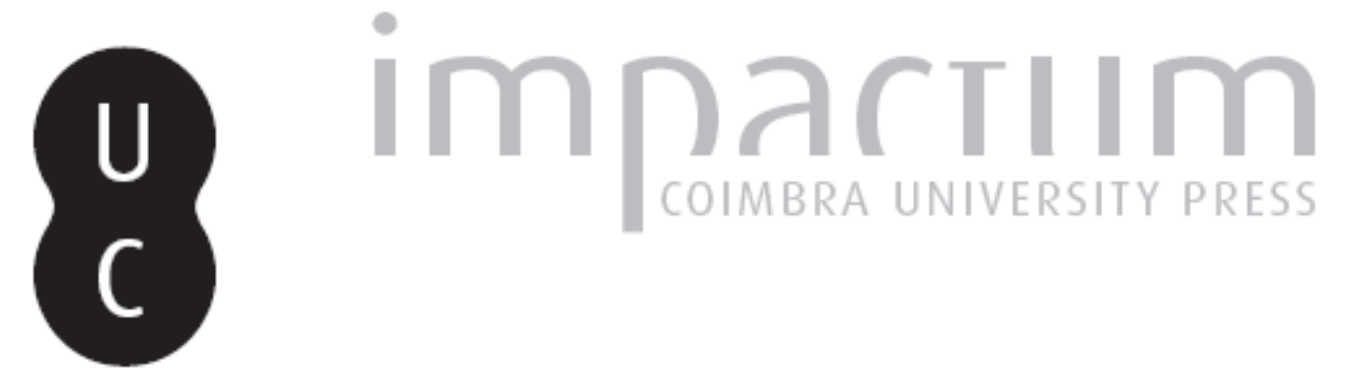

A jurisdicionalização do poder: D. Afonso IV e o Chamamento Geral

Autor(es): $\quad$ Prata, Jorge Manuel de Matos Pina Martins

Publicado por: Centro de História da Sociedade e da Cultura

URL persistente:

URI:http://hdl.handle.net/10316.2/39386

DOI:

DOI:http://dx.doi.org/10.14195/1645-2259_13_4

Accessed : $\quad$ 26-Apr-2023 12:45:34

A navegação consulta e descarregamento dos títulos inseridos nas Bibliotecas Digitais UC Digitalis, UC Pombalina e UC Impactum, pressupõem a aceitação plena e sem reservas dos Termos e Condições de Uso destas Bibliotecas Digitais, disponíveis em https://digitalis.uc.pt/pt-pt/termos.

Conforme exposto nos referidos Termos e Condições de Uso, o descarregamento de títulos de acesso restrito requer uma licença válida de autorização devendo o utilizador aceder ao(s) documento(s) a partir de um endereço de IP da instituição detentora da supramencionada licença.

Ao utilizador é apenas permitido o descarregamento para uso pessoal, pelo que o emprego do(s) título(s) descarregado(s) para outro fim, designadamente comercial, carece de autorização do respetivo autor ou editor da obra.

Na medida em que todas as obras da UC Digitalis se encontram protegidas pelo Código do Direito de Autor e Direitos Conexos e demais legislação aplicável, toda a cópia, parcial ou total, deste documento, nos casos em que é legalmente admitida, deverá conter ou fazer-se acompanhar por este aviso.

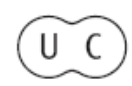



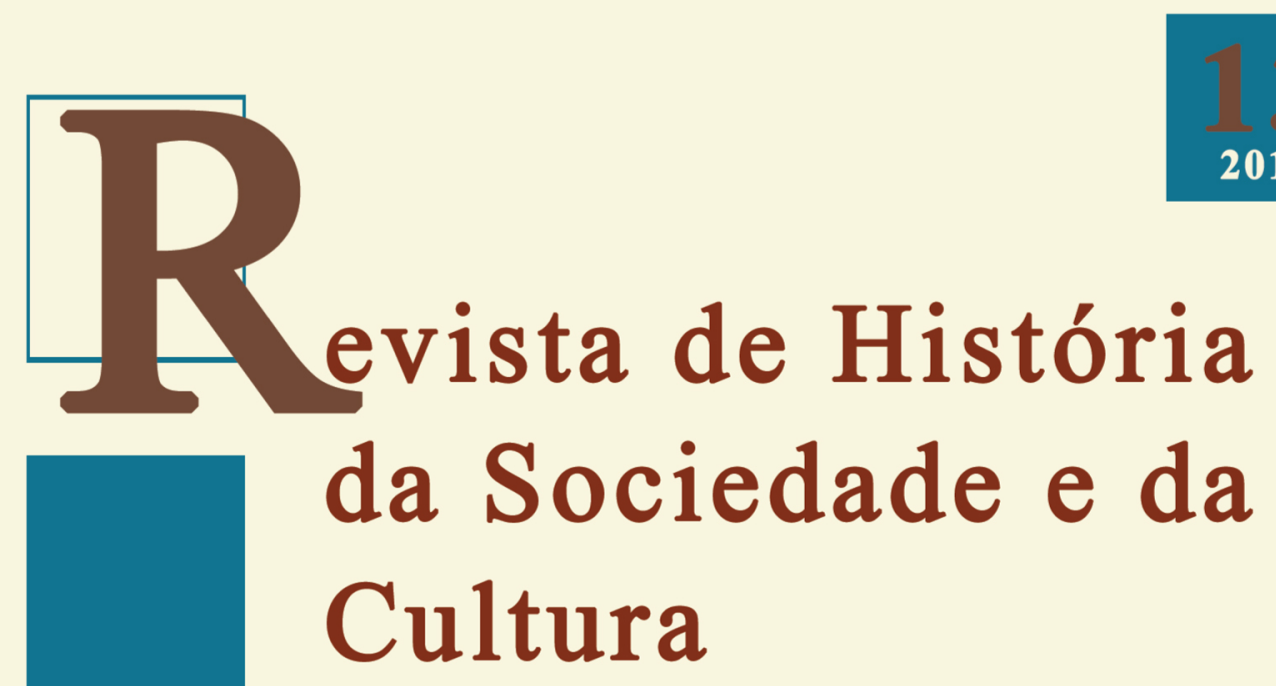

2013

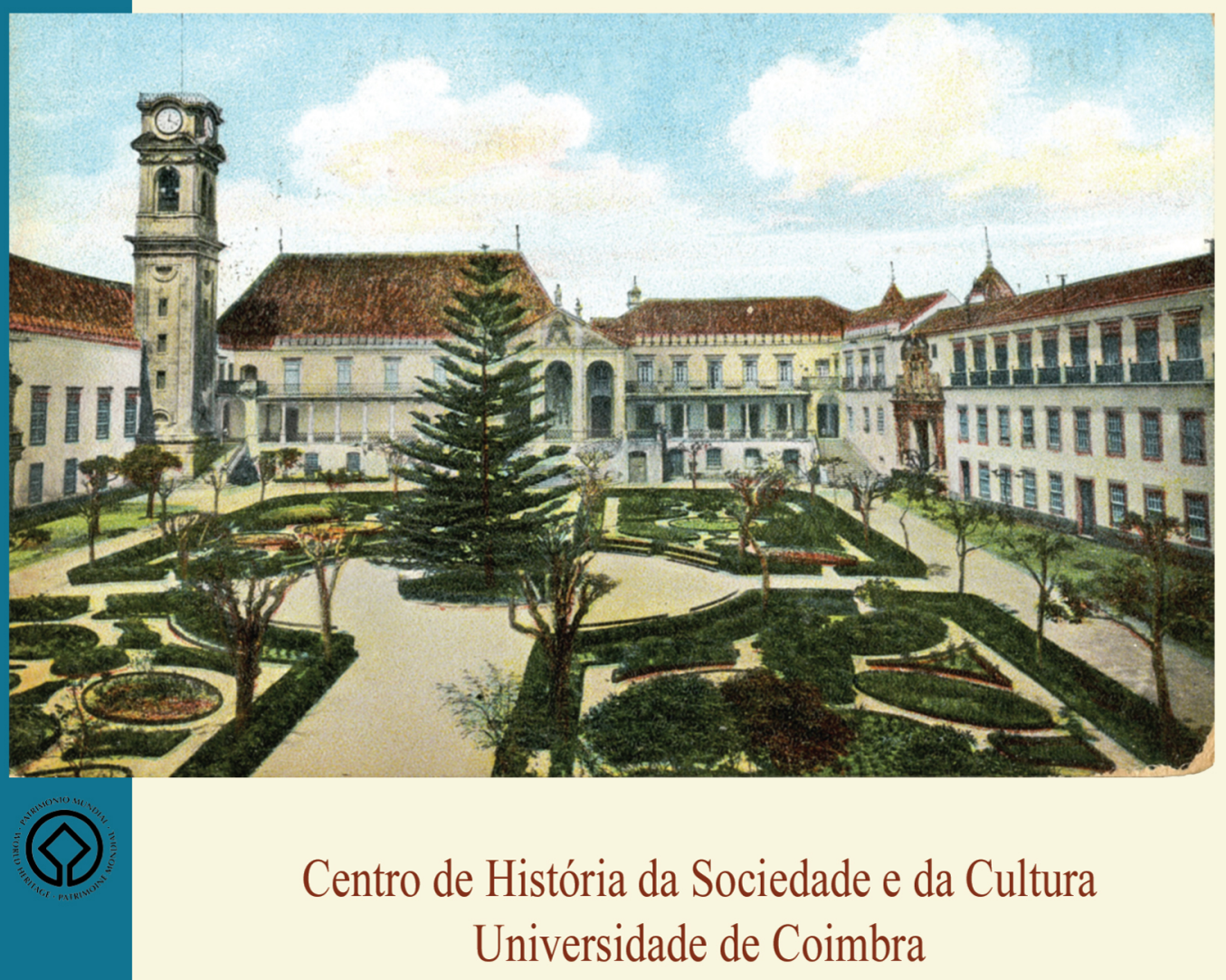

Coimbra 


\title{
A Jurisdicionalização do Poder: D. Afonso IV e o Chamamento Geral
}

\author{
Jorge Manuel de Matos Pina Martins Prata \\ Doutorando em Altos Estudos em História - Idade Média \\ prata@sapo.pt
}

Texto recebido em /Text submitted on: 31/05/2013

Texto aprovado em /Text approved on: 26/06/2013

\section{Resumo/Abstract:}

O Chamamento Geral protagonizado por D. Afonso IV, emergindo do espaço aberto pelo agonismo estrutural que opõe o Rei aos Senhores em torno do exercício jurisdicional, institui-se enquanto dispositivo político através do qual o Monarca vai afirmar a superioridade inequívoca do poder que exerce, na medida em que este se apresenta como fonte e origem de todas as jurisdições, cujo uso por outrem só encontra legitimidade na vontade régia, ou numa disposição legislativa particular, emanando do costume.

Deste modo, mais que a apropriação efetiva das jurisdições, exercidas pelos Senhores, por parte do Monarca, que não deixa de se verificar, embora pontuada por um procedimento de conciliação sucessiva com os interesses que aqueles vão desdobrando junto de D. Afonso IV, trata-se, fundamentalmente, de uma afirmação inequívoca da coessencialidade existente entre jurisdição e oficio régio.

Intercedendo junto do Rei para que este, por sua graça e mercê, não casse as jurisdições de que faz uso, o grupo nobiliárquico acaba por inscrever na sua própria carne os princípios que estruturam o citado dispositivo, numa assunção do poder que exerce como sendo meramente derivado.

The Chamamento Geral starred by D. Afonso IV, emerging from the structural agonism opposing the King to the Lords around the jurisdictional exercising, establishing itself as political mechanism through which the Monarch will unequivocally assert the superiority of the power it exerts, to the extent that it presents herself as the source and origin of all jurisdictions, the use of which by others is legitimate only in the royal will, or in a particular legislative provision, emanating from custom.

Thus, it is not so much the effective appropriation by the monarch of jurisdiction exercised by the Lords but fundamentally an unequivocal affirmation of the essential relation between royal power and jurisdiction.

Interceding with the King for it by his grace and mercy not annul the jurisdictions that uses, the nobility accepts the principles underlying the said device, assuming your power is merely derived.

Palavras chave/Keywords:

Chamamento Geral; Poder; Jurisdições; Processo Judicial.

Chamamento Geral; Power; Jurisdictions; Judicial Process. 


\section{Parergon}

Inserido num enfrentamento que tem como horizonte, por parte do Monarca, a afirmação do que se pode denominar uma soberania jurisdicional, o Chamamento Geral é, também, e talvez principalmente, um facto discursivo, com uma espessura e opacidade próprias, através do qual se pretende legitimar o carácter fundacional da prerrogativa régia de dizer-o-direito, dizer que é ainda, e simultaneamente, autoridade e domínio (ditio), na apresentação de um poder que se concebe como iurisdi(c)tio. Não só, ou nem tanto, apropriação de poderes, mas antes fundamentação de um poder que se quer condição de possibilidade, de iure, de todos os outros.

Trata-se, então, de penetrar na espessa trama do discurso, desentranhar os fios que o constituem, a trama retórico-jurídica em que se delineiam os seus argumentos, e o modo como estes entre si se entretecem. Chamamento Geral cuja textualidade é primordialmente concebida não como descrição de uma qualquer realidade que lhe fosse exterior, mas como dispositivo político, procedimento de configuração das relações de poder.

\section{Do Agonismo Jurisdicional}

A implementação do dispositivo de poder que será o Chamamento Geral ${ }^{1}$, protagonizada por D. Afonso IV, deverá ter começado a gizar-se logo nos primeiros anos do seu reinado, e sido motivada por uma persistente prática de exorbitação dos direitos jurisdicionais exercidos pelo Clero e pela Nobreza.

Assim, por carta régia datada de 1 de Fevereiro de 1331, dirigida ao Meirinho-Mor, Afonso Correia, e aos Corregedores de Além Douro, D. Afonso IV manda que os Juízes dos Coutos e das Honras dêem apelação diretamente para si, e não para o Senhor da terra, a menos que tal seja de uso e costume nesses senhorios. Determina, ainda, que quando degredados ou malfeitores se refugiarem nos ditos domínios as justiças régias os demandem

1 A presente análise do Chamamento Geral debruçar-se-á, apenas, sobre as sentenças inscritas na chancelaria de D. Afonso IV. 
aos Senhores e, caso estes não os queiram entregar, que aí entrem para os prender.

Carta motivada por queixas dirigidas ao Rei, segundo as quais as justiças senhoriais não permitiam que se apelasse, das sentenças por elas proferidas, para o Monarca, nem entregavam aos Juízes concelhios os réus que nessas terras se albergavam, e na qual se inscreve já, de um modo genérico, o projeto global que animaria D. Afonso IV, estruturado em torno de uma concepção política que o instituía como depositário de um poder, não só superior, mas qualitativamente diferente ${ }^{2}$ daquele que os Senhores exerciam nos seus domínios, na medida em que este encontrava no poderio régio o seu fundamento e condição de possibilidade, ainda que esse poder não deixasse de se legitimar, simultaneamente, com recurso para os usos e costumes $^{3}$ do Reino.

Qualidade especifica que possibilitava ao Monarca exigir que as apelações lhe fossem diretamente dirigidas, e ameaçar devassar as terras imunes de quem não respeitasse o uso correto dessas jurisdições.

Antagonismo que tem como condição material de possibilidade um conflito jurisdicional que opõe o Rei aos Senhores, num enfrentamento através do qual se procura desvelar, instituindo-os no mesmo movimento, os alicerces doutrinários em que se funda o direito, e a legitimidade, do exercício de determinado tipo de jurisdições. Uma luta pela determinação dos princípios estruturantes da comunidade e da orgânica do poder, que é, também, uma luta pelo próprio poder, num procedimento agonístico que se encontra já materializado numa carta de D. Dinis de 31 de Julho de $1282 .{ }^{4}$

É no contexto desta conflitualidade surda e ininterrupta, deste agonismo estrutural que se inscreve entre o poder régio e o poder senhorial, criando

2 Contrariamente a Pietro Costa, que afirma que «(...) el vértice no es separable de una cadena de la qual éste es sólo el primer eslabón, y su poder es distinto no ya cualitativamente sino sólo cuantitativamente de los poderes de otros entes o sujetos.» (COSTA, Pietro - La Soberanía en la Cultura Político-Jurídica Medieval: Imágenes y Teorías. Res publica. 17 (2004)33-58), considera-se que o facto de o poder régio se apresentar como condição de possibilidade do exercício de todos os outros poderes, lhe confere um carácter qualitativamente diferenciado.

3 Num procedimento em que se assume o costume como criador de lei. Embora o poder jurisdicional seja privativo do Monarca, não deixa de poder ser exercido por outros, caso um dispositivo legislativo particular o possibilite.

\footnotetext{
${ }^{4}$ Ordenações Del-Rei Dom Duarte. Lisboa: FCG, 1988, p. 165-166.
} 
uma linha de fractura que, não deixando, por vezes, de levar a um afrontamento direto entre ambos, se institui mais como linha estratégica, onde um e outro vão alinhando e (re)compondo forças, num processo de configuração que, separando-as, as une indissoluvelmente, que D. Afonso IV vai proceder, «(...) no início de 1334 (...)» , a um Chamamento Geral, pelo qual vai obrigar os detentores de Coutos e Honras, e de qualquer tipo de jurisdições, a comparecerem perante os Ouvidores dos feitos de El Rei, para, na sua presença, enumerarem as terras imunes que detêm, e legitimarem a sua posse e o exercício das jurisdições de que nelas usam; não o conseguindo, estas ser-lhes-ão cassadas. ${ }^{6}$

Chamamento Geral, dobrado por um Chamamento Particular, através do qual alguns Senhores vão ser individualmente citados, ${ }^{7}$ mas ao qual, no entanto, muitos se escusaram a comparecer.

Em face desta recusa, configuradora de uma vontade de rebeldia, na medida em que expressamente manifestava uma atitude de desobediência a um mandado régio por partes dos Senhores, D. Afonso IV, embora afirmando que $«(. .$.$) a esses que nom quiserem viir satisfazer ao meu mandado (...)$ podesse de dereito mandar lançar em devasso todallas honrras, que am, e tragem no meu Senhorio pellas ditas Inquirições; $(\ldots) »^{8}$ decide, logo em 1335, por carta régia de 10 de Janeiro, enviar Geraldo Esteves às comarcas da Beira e de Trás-os-Montes, para devassar apenas as honras que tivessem sido

5 SOUSA, Bernardo Vasconcelos e - D. Afonso IV. Lisboa: Temas e Debates, 2009, p. 128. No protesto apresentado pelo Arcebispo de Braga perante os Ouvidores dos Feitos de El Rei, em Santarém, no último dia de Fevereiro de 1334 (Livro Das Leis E Posturas. Lisboa: FDUL, 1971, p. 382-395), ao qual juntou a sua voz o Bispo de Viseu, faz-se referência a uma determinação de D. Afonso IV, segundo a qual todos os prelados do Reino deveriam fazer prova, junto dos Ouvidores régios, até ao dia 1 de Março desse mesmo ano, dos títulos de posse dos Coutos, Honras, Jurisdições e Terras que possuíssem. Tratando-se a citada determinação, como tudo leva a crer, do Chamamento Geral promulgado por vontade do Monarca, e tendo em conta que este, por carta de 2 Janeiro de 1344 (Ordenações Del-Rei..., cit., p. 534-535), concede aos Fidalgos que não compareceram perante os Ouvidores dos Feitos de El Rei, tal como o édito decretava, o prazo de três meses para o fazerem, a contar da data de publicação da mesma, ou após lhes terem sido restituídas as jurisdições pelo Corregedor, este deve datar de finais de 1333, na medida em que não parece crível que o prazo constante do édito fosse inferior ao concedido aos Fidalgos em 1344.

6 Chancelarias Portuguesas: D. Afonso IV. Lisboa: INIC, 1992, Vol. III, p. 201-202.

7 Chancelarias..., cit., Vol. III, p. 217.

8 Memorias Para A Historia Das Inquirições Dos Primeiros Reinados De Portugal. Lisboa: Impressão Régia, 1815, Docs., p. 122. 
criadas, ou alargadas, após as Inquirições de 1288. D. Afonso IV concede, assim, «(...) em quanto for minha merçe (...)»" que os Senhores mantenham as terras imunes, com as referidas jurisdições, no estado em que existiam à data da realização das citadas inquirições dionisinas. Procedimento de adequação aos interesses da Nobreza que não deixa de ser marcado por uma afirmação inequívoca da proeminência do poder régio, ao assinalar que tal disposição não configura uma determinação de direito mas sim de graça, dela emergindo, portanto, um dispositivo iminentemente precário, já que revogável a qualquer instante. As jurisdições assim exercidas não pertencem em próprio aos que as detêm, não constituindo a sua posse um direito que tenham a possibilidade de alegar, sendo antes um uso gracioso, estatuído fora, e para além, do direito.

Carta que se inicia com um longo prólogo, no qual se faz um historial, desde o reinado de D. Dinis, da conflitualidade constante que se entretece entre os Senhores e o Rei a propósito da constituição de terras imunes, e das jurisdições nestas exercidas, marcado por uma prática insistente de alargamento dos seus poderes jurisdicionais, e da base territorial em que se exercem, por parte dos fidalgos do seu reino, apesar das constantes mercês régias que iam adequando o exercício do poder aos interesses da Nobreza, e das composições que entre os contendentes se iam instituindo.

Mas aquela prática encontra-se inscrita na carne e no sangue do grupo nobiliárquico, constitui com ele um todo indissolúvel que não só o marca, como é condição de possibilidade da sua emergência enquanto tal. Persiste, portanto, numa insistência que dá a ver a sua essencialidade para o corpo de que é uma manifestação imediata. E D. Afonso IV tem de confrontar-se, inevitavelmente, com este questionamento prático dos princípios estruturantes do poder régio que, por direito, exerce, e com os insistentes protestos dos povos.

Narrativa que desdobra, perante aqueles a quem se destina, uma história de afrontamento constante do direito instituído e do poder que, nele se fundando, o deve preservar, e exercer com vista à sua manutenção e inscrição no todo da comunidade, e de obrar gracioso, através do qual o Rei vai condescendendo com os interesses fundamentais de um grupo que, pela sua

9 Memorias..., cit., Docs., p. 121. 
importância e dignidade, não pode deixar de ser objecto de agraciamento por parte daquele que tem por função distribuir a cada órgão do corpo político os benefícios que lhe são devidos, tendo em conta o estatuto natural de cada um. História de benevolência régia e de soberba da Nobreza, que não pode deixar de ter como consequência a implacável imposição do Direito. Um libelo de propaganda, portanto.

Justificado e legitimado o empreendimento, Geraldo Esteves deambula, logo em 1335 e, depois, em 1340, pelas comarcas da Beira e de Trás-os-Montes «(...) pera deuassar e filhar pera mjn todalas Juridições $(\ldots)\rangle^{10}$, o mesmo o fazendo João Domingues em 1339.

Por ordem expressa do monarca, embora subliminarmente enunciada e ao arrepio do inscrito na textualidade oficial, ou por intencionalidade autónoma dos oficiais régios incumbidos de executar o processo de devassas, verifica-se que estes retiram, ou pretendem retirar, as jurisdições possuídas pelos Senhores ainda quando estas constam das inquirições mandadas efetuar por D. Dinis em 1288, ou quando eram objecto expresso de doação régia, avalizada por prova documental.

Mas não era, apenas, a atuação prática dos Inquiridores enviados pelo Rei às comarcas que ameaçava a afirmação dos poderes jurisdicionais da fidalguia, focando-se a preocupação do grupo nobiliárquico, também, na forma como os Ouvidores dos feitos de El Rei iam desdobrando os processos dos que perante eles compareciam, dando cumprimento ao disposto no Chamamento Geral, pelo que se dirigem a D. Afonso IV, em $1341^{11}$, queixando-se porque aqueles não querem aceitar, como provas cabais de posse de terras imunes e de jurisdições, a sua inscrição nas inquirições dionisinas de 1288. Afirmam, ainda, que têm como propriedade honras não contidas nas citadas inquirições, ainda que delas estejam em posse desde o tempo em que estas foram tomadas, mas que, querendo prová-lo, os Ouvidores não aceitam receber as suas razões e as provas que as sustentam.

Posição dos oficiais régios que se fundamenta na aceitação do direito invocado pelo Procurador do Rei, que esgrime as suas razões ancorando-as em dois argumentos fundamentais:

\footnotetext{
${ }^{10}$ Chancelarias..., cit., Vol. I, p. 388.

${ }^{11}$ Chancelarias..., cit., Vol. III, p. 201-203.
} 
$1^{\circ}$ : D. Dinis determinara, por sentença ${ }^{12}$, com o conselho da sua Corte, que a posse de uma Honra não legitimava, só por si, que nela se instituíssem Juízes, Ouvidores e Chegadores, pelo que nos casos em que tal se verificou a jurisdição é nula;

$2^{\circ}$ : mesmo que a citada sentença não existisse «(...) per dereito nom poderiam trastempar as dictas Jurisdições. saluo sse Alegassem e prouassem que as possoyam ante que as dictas Enquirições fossem filhadas per tanto tempo que a memoria dos homens nom era en contrairo.» ${ }^{13}$

Estrutura argumentativa que mostra que a legalidade do exercício jurisdicional não se fundava, apenas, numa expressa doação régia, mas que podia legitimamente adquirir-se por usucapião, sendo o prazo requerido para tal desde que a memória dos homens não fosse em contrário. Verifica-se, ainda, uma divergência entre o tipo de prova exigido pelos Ouvidores e o que era determinado pela carta régia de 10 de Janeiro de $1335^{14}$.

Enquanto aqueles, para pronunciarem sentença que confirmasse o exercício das jurisdições alegadas pelos Senhores, obrigavam a que estes produzissem prova de que delas usavam, aquando das inquirições de 1288, desde que a memória dos homens não fosse em contrário, a referida carta régia apenas determina que estes provem que as detinham na data em que as inquirições supracitadas se realizaram. Obliterando a vontade régia, expressa por documento escrito, os Ouvidores julgam em função do direito comum, não obstante a disposição do monarca, marca inequívoca de uma certa autonomia do tribunal face ao Rei.

Verifica-se, assim, a existência de uma conflitualidade estrutural entre a aplicação concreta das normas pelos tribunais régios, e o estatuído nas mercês que o Soberano ia dispensando aos Senhores do seu Reino, na medida em que os Ouvidores dos feitos de el Rei julgavam em função da lei e do direito, e não em função do instituído pelas citadas mercês. O que demonstra que estas não revogam, pelo menos na totalidade, o direito

${ }^{12}$ Trata-se de uma das sentenças inscrita numa carta dirigida a Aparício Gonçalves, datada de 20 de Outubro de 1308 (Ordenações Afonsinas. Lisboa: FCG, 1998, Liv. II, p. 412).

${ }^{13}$ Chancelarias..., cit., Vol. III, p. 202.

${ }^{14}$ Memorias..., cit., Docs., p. 119-122. 
à época existente, numa vigência cumulativa que tornava o ordenamento jurídico ${ }^{15}$ uma intrincada composição, tecida de fios diversos e divergentes.

D. Afonso IV, no entanto, «(...) querendo lhis fazer graça e merçee $(\ldots) »^{16}$, determina que os fidalgos se mantenham na posse das jurisdições que alegam deter se provarem que as exercem desde há sessenta anos, à data em que foi enunciado o Chamamento Geral, tanto no que se refere às que constam das inquirições de 1288, como às que nelas não se encontram inscritas, ainda «(...) que pela dicta sentença que per meu padre e per sa Corte foy dada nom podesse põer Juiz nem ouuydores nem chegadores nas honrras que an nem sse podessem Aiudar de trastempo per dereito senom pela guisa que era dicto pelo meu procurador $(\ldots)\rangle^{17}$, embora tal decisão apenas se aplique aos pleitos que ainda decorrem entre os Senhores e o Rei, ficando dela excluídos todos os casos julgados, bem como os dos Senhores que não compareceram ao dito Chamamento régio.

Deste modo, o Monarca coloca-se, intencional e inequivocamente, acima da lei e do direito positivo, liberto dos preceitos por estes constituídos, e afirmando-se, portanto, como legibus solutus.

Apesar da lei promulgada por D. Dinis em $1308^{18}$ proibir aos fidalgos que estão na posse legítima de honras, que nelas instituam Juízes ou Ouvidores, onde antes eles não o faziam, apropriando-se de um poder jurisdicional que lhes não pertence, e de o direito determinar que a prescrição aquisitiva só se verifica quando o uso das jurisdições é exercido, continuadamente, e sem qualquer interrupção da prescrição, por um período em que a memória dos homens não é em contrário, D. Afonso IV, não obstante estes dispositivos de direito, concede aos Fidalgos a mercê de disporem lidimamente das honras e jurisdições que detivessem desde $1273^{19}$, numa clara ab-rogação parcial do direito positivo então vigente.

Contrariando o direito em vigor na matéria em causa, o Rei concede aos Fidalgos, que ainda têm pleitos a decorrer com o Monarca referentes à

${ }^{15}$ No sentido que lhe é atribuído em GROSSI, Paolo - L'Ordine Giuridico Medievale. Bari: Laterza, 2011.

${ }^{16}$ Chancelarias..., cit., Vol. III, p. 202.

${ }^{17}$ Chancelarias..., cit., Vol. III, p. 202-203.

18 Ordenações Afonsinas..., cit., Liv. II, p. 412.

${ }^{19}$ Isto, se se considerar que o Chamamento Geral se realizou em 1333. 
questão das jurisdições das terras imunes, o privilégio, contrário ao direito, de continuarem a exercer o poder jurisdicional cujo uso provem deter sessenta anos antes da proclamação do édito.

Ao não dotar de retroatividade o privilégio em apreço, D. Afonso IV cria uma fissura no espaço da prática judicial, nos interstícios do qual se inscreve um princípio de injustiça ${ }^{20}$, na medida em que a mesma matéria julgada será dirimida por regras diferentes, o que implica a existência de sentenças diversas para casos iguais, por efeito, apenas, da data de pronúncia da referida sentença.

Alteridade de juízo que vem contradizer o dispositivo legitimador da retroatividade da lei sobre a vindicta de 11 de Março de $1325^{21}$, segundo o qual «E seria desygualdade auere'-no de fazer huuns por o que he passado E outros a que esto perteençe d'acooimar nom o poderem fazer (...).» ${ }^{22}$

Generalidade da lei que é expressamente afirmada, no que se refere ao carácter isotrópico do espaço para o direito, num processo de abstração das marcas valorativas que, nele se inscrevendo, fazem com que, socialmente, certos locais sejam considerados como tendo maior dignidade que outros, e considerando estas como meros acidentes que não alteram a essência fundacional daquele, numa lei de 23 de Fevereiro de $1325^{23}$, pela qual D. Afonso IV revoga outra de D. Dinis que proibia desafios entre Fidalgos num espaço de duas léguas ao redor do local onde o Rei se encontrasse, «(...) porque o poymento da lley ssobredita nom tolhia desfiar ssenom em certo lugar E per ualymento do lugar nom deue lley nem direjto sseer desuairado. ca deue sseer Jeerall o que a dita lley nom Era ${ }^{24}$

Conduta maculada por uma injustiça lega $l^{25}$ que se justifica pelo facto de o Monarca, enquanto dispensador de graça, não estar submetido aos procedimentos ordinários, alcandorando-se ao exercício de uma potestas absoluta que o coloca acima da lei positiva, ainda que o ato de agraciar se institua contra ius, ou mesmo lesando os iura quaesita, desde que

${ }^{20}$ A «desygualdade». Ordenações Del-Rei..., cit., p. 375.

${ }^{21}$ Ordenações Del-Rei..., cit., p. 373-376.

${ }^{22}$ Ordenações Del-Rei..., cit., p. 375.

${ }^{23}$ Ordenações Del-Rei..., cit., p. 376-378.

${ }^{24}$ Ordenações Del-Rei..., cit., p. 377.

${ }^{25}$ Enquanto contrária à lógica das disposições régias, introduzindo uma lógica outra na resolução dos diferendos. 
tal processo gracioso não lese o direito de terceiros e seja proveitoso ao peticionário, e se apresente enquanto condição de possibilidade da resolução de problemas que afectem a comunidade no seu todo.

Condicionantes do exercício do poder extraordinário, de que o Rei se reveste nestes atos, que se encontram reunidas no caso em apreço, na medida em que a outorga da mercê pela qual D. Afonso IV concede, aos Senhores do seu Reino que ainda têm com ele pleitos litigiosos decorrentes da promulgação do Édito, a posse das honras e jurisdições que comprovadamente lhes pertencessem em 1273, não só pode ser concebida como não prejudicial para ninguém, como serviria para apaziguar os ânimos de uma Nobreza inquieta e conflituosa, deste modo contribuindo para assegurar a concórdia comum que deve imperar em qualquer Reino bem regido.

Tendo ficado excluídos da mercê régia todos aqueles que não se apresentaram ao Chamamento Geral promulgado pelo Soberano português, Gonçalo Eanes de Briteiros e Vasco Martins Zote, na qualidade de procuradores dos fidalgos, compareceram perante o Monarca ${ }^{26}$, agravando-se-lhe por as terras pertencentes aos Nobres que não tinham respondido ao citado Chamamento estarem a ser devassadas pelo Corregedor de Entre Douro e Minho, e pedindo-lhe, por sua graça, que tal ato de rebeldia não seja considerado causa suficiente para que as jurisdições lhes sejam cassadas, e possam manter-se na sua posse tal como antes as haviam, comprometendo-se eles, em nome da fidalguia, em que os Senhores em causa compareceriam perante os Ouvidores do Rei, no dia que este aprazasse.

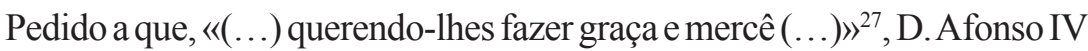
acede, ordenando «(...) que nom percam Jurdiçoees deses coutos por nom uyrem a edito.» ${ }^{28}$, desde que os fidalgos cumpram o prometido, pois, caso o não façam, «(...) sejam logo deuassados esses coutos E filhadas as Jurdiçoees pera mym. ${ }^{29}$

Num procedimento que denuncia a veracidade das afirmações relativas ao acrescentamento das terras imunes por parte da Nobreza, bem como à apropriação indevida de jurisdições exercidas pelo Rei, os mesmos Gonçalo

\footnotetext{
${ }^{26}$ A 2 de Janeiro de 1344.

${ }^{27}$ Ordenações Del-Rei..., cit., p. 535.

${ }^{28}$ Ordenações Del-Rei..., cit., p. 535.

${ }^{29}$ Ordenações Del-Rei..., cit., p. 535.
} 
Eanes de Briteiros e Vasco Martins Zote solicitam ao Monarca, logo a 3 de Janeiro de 1344, que a data limite aceite para a legítima constituição de honras fosse alterada, e que se considerassem lídimas todas as que foram criadas até 1305 , vinte anos antes da morte de D. Dinis, aceitando que fossem devassadas todas aquelas que tenham sido formadas após essa data.

Solicitação que, mais uma vez, será benevolamente apreciada pelo Rei, anuindo este às pretensões enunciadas pelos fidalgos, e concedendo-lhes, ainda, que nas terras honradas não entrem nem o Mordomo nem o Saião régios, sendo o direito ao exercício de jurisdições determinado em função do que constar das inquirições realizadas ${ }^{30}$.

Determinação régia que, no entanto, parece não ter tido um total acolhimento por parte dos Juízes, que devem ter continuado a julgar alguns pleitos em função da lei existente, e não da graça pelo Rei outorgada, diferendo esse que justifica que D. Afonso IV tenha enviado, a 27 de Outubro de 1344, uma carta aos seus Ouvidores, através da qual «(...) El Rej uos manda que guardees aos filhos d'algo do seu Senhorio a graça e merçee que lhes fez em rrazom das honrras pella guisa que na carta que lhes desto mandou dar he conthudo posto que nom uyesem a edito $(\ldots))^{31}$.

\section{Estrutura processual}

Citação. O processo inicia-se pela constituição da carta citatória, na qual se desdobram as razões que determinam a demanda, e obrigam à comparência dos demandados perante os Ouvidores dos feitos de El Rei: os citados deverão apresentar-se para enumerarem as terras imunes que possuem e as jurisdições que aí exercem, legitimando o seu uso perante as justiças régias.

Citação que se faz quer através de um Chamamento Geral, pelo qual são indiscriminadamente apregoados todos aqueles que exercem qualquer tipo de jurisdição em terras do Reino, quer através de um Chamamento

\footnotetext{
${ }^{30}$ As mandadas realizar por D. Dinis, no que tange às honras que delas constam e, no que se refere às que nelas não estão inscritas, pelas que $\mathrm{D}$. Afonso IV ordenar, no sentido de confirmar a sua existência desde, pelo menos, 1305.

${ }^{31}$ Ordenações Del-Rei..., cit., p. 535-536.
} 
Particular, dirigido a um só Senhor ou Instituição específica, levado a cabo por Geraldo Esteves, na Comarca da Beira e Além Montes, e por Lourenço Martins Calado, na Comarca de Entre Douro e Minho.

Por este último método são citados vinte e seis Senhores ou Instituições, sem que se consiga perceber muito bem a razão pela qual são objecto deste específico modo de Chamamento. Note-se, no entanto, que todas as citações de carácter individual se verificam entre os anos de 1335 e 1337, constituindo mesmo mais de metade do total das citações verificadas nesse espaço de tempo (23 em 45, não contando as três cuja data se apresenta indeterminável, embora não seja crível que estas se enquadrem num arco temporal diferente), e que apenas o Mosteiro de Santa Maria de Pombeiro pode ser integrado num quadro composto, de entre os demandados, pelos senhorios de maior importância territorial e jurisdicional.

Segundo José Eduardo Marques dos Santos, o recurso à citação por édito verificava-se: «a) sempre que a pessoa que havia de ser citada não era certa ou, sendo-o, não fosse certo nem sabido o lugar onde se encontrava; b) quando, sendo certo e sabido o local onde se encontrava, o réu fosse uma pessoa de tal modo poderosa que tivesse por costume tratar mal aqueles que o iam citar pessoalmente; c) ou ainda, não sendo poderoso, isto é, fosse de pequeno estado e condição, morasse em lugar perigoso onde aquele que o havia de citar não pudesse ir em segurança.» ${ }^{32}$

A inexistência de um conhecimento cabal de quem exercia efetivamente, no Reino, um qualquer poder jurisdicional, ou então, embora pouco verosimilmente, a eminência do poder exercido, e o carácter belicoso e irreverente perante as ordens régias, de determinados Senhores, talvez tivesse imposto o tipo de citação por édito.

Resta saber a razão pela qual alguns serão nominalmente citados.

Comparência em Juízo. Após a citação, o Demandado, ou o(s) seu(s) Procurador(es), apresenta(m)-se na audiência dos feitos de El Rei perante um ou dois Ouvidores desse tribunal (nesta fase do processo não era necessária a presença de dois Ouvidores), e desdobra as suas razões, referindo as

${ }^{32}$ SANTOS, José - O Processo Penal Português no Período Medieval.Porto: Ecopy, 2012, p. 287-288. 
terras imunes que possui, bem como os poderes jurisdicionais, e os direitos, que nelas exerce.

Exceções a este procedimento constituem os quatro processos em que intervém o Bispo do Porto, Vasco Martins, nos quais este comparece não perante os Ouvidores mas diretamente perante o Rei, apesar de ter sido citado, por chamamento geral, perante aqueles.

Após a descrição do que lhe era pedido na carta citatória, o Demandado procede à legitimação do exercício das jurisdições que alegara, legitimação essa que consiste, na esmagadora maioria dos casos (noventa e cinco em cento e dezanove), na mera, e única, assunção do seu exercício 'per tanto tenpo que a memoria dos homens nom era en contraijro', num procedimento legitimador que fundamenta o direito no uso e costume. O simples facto de se exercerem determinado tipo de jurisdições durante um dado lapso de tempo, torna legítimo esse mesmo exercício, transmutando o facto em direito.

Nos processos em que intervêm como demandados Pero Botelho, Fernão Rodrigues de Besteiros, Pero Martins de Basto, Martim Rodrigues Airó, Vasco Martins Zote, Fernando Afonso, Maria Gonçalves e Leonor Furtado, Beringueira Anes, Fernão Furtado, Mosteiro de Pombeiro, Cabido da Sé de Braga, Rodrigo Eanes de Sandim, Álvaro Peres Gonçalves, Vasco Afonso Martins e Rui Novais verifica-se, nesta fase do desdobramento processual, o recurso, quer isoladamente, quer em conjunção com a legitimação por exercício 'intemporal', à apreciação de prova documental: os Demandados, ou os seus Procuradores, pedem que sejam analisados os róis das inquirições mandadas realizar por D. Dinis, e que se julgue o feito em face do que aí se encontrar inscrito. Esta pretensão é aceite pelo procurador do Rei, o que determina a pronúncia imediata da sentença definitiva logo após a análise dos referidos róis.

Sentenças que, com exceção da referente ao pleito com Pero Martins de Basto, em que lhe é cassada a jurisdição cível, confirmam todos os direitos e poderes judiciais arrazoados pelos Demandados ${ }^{33}$. Note-se, no entanto,

${ }^{33}$ O que demonstra, cabalmente, o carácter decisório do Documento Escrito. A oralidade, mau grado ser, ainda, o meio fundamental e estruturante de prova, perde prestígio e força vinculativa que, pelo contrário, é assumida, de modo despótico e inquebrantável, pela escrita. 
que de entre estes quinze processos apenas em quatro se alega o exercício de um qualquer tipo de jurisdição, em três casos a cível e num a cível e criminal.

Análise dos róis das inquirições dionisinas que, no caso dos quatro pleitos com o Bispo do Porto, é duplicada pela realização de novas inquirições a mando de D. Afonso IV, efectuadas por Afonso Peres de Constantim e Domingos Esteves de Paços, para que fosse mais certo da verdade ${ }^{34}$.

Em três outras demandas, com o Cabido da Igreja de Santiago de Compostela (duas), e com o Mosteiro de São Paio de Antealtares, os Procuradores das citadas Instituições apresentam cartas de privilégio que provam o exercício dos direitos por estes alegados, o que tem, também, como consequência imediata o encerramento do pleito, com pronúncia de sentença a confirmar todas as suas jurisdições e direitos.

Há ainda mais quatro casos, no entanto, em que a demanda termina nesta fase processual: os referentes à Igreja do Cossourado, a Afonso Gomes e Sancha Fernandes, ao Mosteiro de Loivo e à Ordem do Hospital. No primeiro, é o próprio Procurador do Rei a afirmar a existência de prova documental ${ }^{35}$ que confirma o exposto nas suas razões pelo Demandante, não sendo requerida a sua análise e confirmação, e pondo, deste modo, fim ao pleito; e, nos restantes, aquele desiste simplesmente da querela, sem qualquer justificação adicional.

Petição (ou Libelo). Expostas as razões pelo Demandado, ou pelo(s) seu(s) Procurador(es), o Demandante elaborava a sua petição, pela qual dava forma, e fundamentava, as suas pretensões no tocante à querela em causa.

Neste momento constata-se, invariável e sistematicamente (excepto nos casos em que o pleito já foi dirimido, não havendo, portanto, lugar à produção de petição), a inscrição de uma mesma textualidade argumentativa, através da qual se procura provar que todas as jurisdições devem ser exercidas pelo Rei, na medida em que lhe pertencem por direito comum.

${ }^{34} « \mathrm{E}$ eu pera ser mays certo de quanto tempo auia que a dicta Egreia do porto estaua en posse dos dictos Coutos e das Jurisdições que hi tragia (...) mandei hy fazer enquirições (...)» (Chancelarias ..., cit., Vol. III, p. 112). O que mostra, de modo evidente, a importância do tempo de uso para a legitimidade, ou não, do exercício das jurisdições.

35 As inquirições mandadas realizar por D. Dinis. 
Nas três querelas em que intervém Gonçalo Eanes de Briteiros, o Procurador régio faz ainda apelo a uma lei de D. Dinis ${ }^{36}$, para provar a legitimidade das pretensões do Rei.

Fase que já não se caracteriza, apenas, pelo estabelecimento das questões de facto, em que se procura narrar, com toda a veracidade e fidedignidade possíveis, os feitos que estão na base do processo, mas no qual se pretende, também, determinar o direito a aplicar em face dos dados apresentados, e que cada uma das partes por si pode haver. Trata-se, portanto, de rezoar o feito, estruturando as alegações, que podem ser «(...) de direito ou de custume ou de foro ou de postura da terra ou de leis del Rey ou doutra hordenaçom boa $(\ldots))^{37}$

Defesa. À petição opõe o Demandado a defesa, na qual afirma não ter de abdicar do uso das jurisdições ${ }^{38}$, na medida em que as exercia por direito ${ }^{39}$, tal como tinha alegado nas razões.

Nesta fase poderia haver réplica e tréplica mas, nos casos em apreço, o Procurador régio limita-se, na quase totalidade dos casos, a anular a defesa com um liminar «o nom sabja nem crija» ${ }^{40}$, através do qual invalidava a palavra dada pelo Demandado, afirmando que não a aceitava como legítima por não acreditar no que, por ele, fora pronunciado.

Artigos de Prova. Apresentadas pelos litigantes as razões que sustentam as posições que assumiram relativamente ao processo passa-se, então,

${ }^{36}$ «E giraldo steuez meu procurador por mim dizia que era Julgado per El Rey Don Denis meu padre com ssa Corte que nenhua onrra por onrrada que fosse que nom metesse o senhor dela hy chegador nem Juiz e que entrasse en elas o sseu porteiro e fossem os moradores delas perante o Juiz da terra en cuio Julgado Jouuessem a ffazer dereito (...).» (Chancelarias..., cit., Vol. III, p. 222)

${ }^{37}$ Ordenações Del-Rei..., cit., p. 332.

${ }^{38}$ Só num processo a Defesa se apresenta com uma estrutura discursiva diferente (Mosteiro de Bouro), produzindo-se, neste caso, uma afirmação de vontade de prova.

${ }^{39}$ Direito este que tem o seu fundamento no uso, numa prática imemorial. Trata-se da possibilidade de apropriação das jurisdições por prescrição aquisitiva, já inscrita nas Sete Partidas (Afonso X - Las Siete Partidas, Glosadas por el Licenciado Gregorio Lopez. Madrid: Boletín Oficial del Estado, 1985, Vol. I, 2 ${ }^{a}$ Partida, Tít. II, Ley XII, p. 8), e para a qual é necessário que a posse se verifique «per tanto tempo que a memoria dos homens nom era en contrairo» (Chancelarias..., cit., Vol. III, p. 202).

${ }^{40}$ Procedimento de defesa que, não confessando nem negando, antes tentando invalidar o enunciado do Demandando, tinha a sua possibilidade de utilização explicitamente inscrita numa ordenação sem data, mas possivelmente do ano de 1331 ou anterior. (Ordenações Del-Rei..., cit., p. 317). 
à apresentação dos artigos de prova, quer pelo Demandante, quer pelo Demandado. Nestes, ambos referiam aquilo que consideravam ser os factos em que alicerçavam as suas pretensões, obrigando-se a prová-los ${ }^{41}$.

Num processo referente à Aldeia de Santa Marinha, pertença do Mosteiro de Santa Cruz de Coimbra, apresenta-se como artigo uma prova documental: uma carta de privilégio de D. Sancho.

Julgados por pertencentes ${ }^{42}$, ou seja, pertinentes ao feito em questão, procedia-se, então, à nomeação dos inquiridores, que iriam proceder à averiguação da veracidade dos artigos alegados, o que era feito por um procedimento oral, questionando as testemunhas nomeadas pelas partes. Os inquiridores eram, também, escolhidos pelos litigantes, constituindo-se dois grupos, ambos compostos por membros indicados pelas duas partes: um averiguava a veracidade dos artigos do Demandado e outro a veracidade dos artigos do Demandante.

${ }^{41}$ Equivoca-se, portanto, José Marques quando afirma que «Normalmente, o procurador do rei, quando não dispunha de elementos para contraditar as provas apresentadas pelos titulares inquiridos, invocava a interrupção do exercício da ou das jurisdições em causa, obrigando, assim, os referidos titulares a aduzirem novas provas. Por vezes, era precisamente nesta fase do processo que o procurador e os ouvidores encontravam elementos para iniciarem um autêntico processo contraditório.» (MARQUES, José - D. Afonso IV e as Jurisdições Senhoriais in AA.VV. - Actas das II Jornadas Luso-Espanholas de História Medieval. Porto: INIC, 1990, Vol. IV, p. 1527-1566, maxime IV, p. 1535) Nesta fase não se trata de contraditar provas, mas de apresentar aquilo que se quer provar. Aliás, que provas haveria a contraditar já que, não havendo prova documental, apenas existiam as afirmações das partes que, aliás, o Procurador do Rei já tinha descartado como irrelevantes, com a frase sacramental: 'nom sabja nem crija'. Nem se inicia, portanto, um contraditório. Afirmações, apenas; que ficarão à espera de algo que as prove: as inquirições. A invocação de interrupção, por parte do Procurador régio, não significa, também, «a interrupção do exercício da ou das jurisdições» (MARQUES, José - D. Afonso IV ..., cit., p. 1535), ou seja, a existência de prescrição aquisitiva por parte do Monarca, mas a afirmação de que os factos que apresentará, e posteriormente provará, terão como consequência a vitória na demanda e, deste modo, determinarão a interrupção do exercício das jurisdições em causa pelo demandado. Interpretação corroborada pela justificação da sentença dada no pleito entre o Rei e o Mosteiro de Santo Tirso de Riba de Ave, a propósito da Honra de Guimarei: «Os meus Ouujdores. vistas as dictas Enquirições e Abertas e pobricadas acharom que o dicto Momsteiro prouaua que metia chegador na dicta honrra des. Sasséénta Anos áa cá. ssaluo des quatro Anos que Auja que entrauam hj os meus porteiros a ffazer as penhoras e entregas e assy o Julgarem per Sentença.» (Chancelarias..., cit., Vol. II, p. 94).

${ }^{42}$ Só num caso, referente ao pleito com o Mosteiro de São Salvador da Torre, os artigos são considerados como não pertencentes, a pedido do Procurador do Rei. 
Abertura das Inquirições. Após as testemunhas apresentadas por cada uma das partes, a provarem os artigos alegados, terem sido inquiridas no local onde os eventos relacionados com o processo tinham ocorrido, os testemunhos eram passados a escrito pelo tabelião e enviadas para a audiência dos feitos de el Rei, onde o pleito estava a ser julgado. Procedia-se, então, à sua abertura e análise por parte dos dois Ouvidores ${ }^{43}$.

Por vezes aproveita-se, ainda, esta ocasião para a apresentação de prova documental a juntar às Inquirições ${ }^{44}$, como sucedeu em seis casos, três relativos a pleitos envolvendo o Mosteiro de Santa Cruz de Coimbra (carta de privilégio de D. Sancho II, o que leva o Procurador do Rei a desistir da demanda relativa à jurisdição cível e restantes direitos alegados, mantendo a concernente a crime de morte - Aldeias na zona de Seia; carta de privilégio de D. Sancho I, o que leva o Procurador do Rei a desistir da demanda relativa à jurisdição cível e restantes direitos alegados, mantendo a concernente a crime de morte - Aldeias não especificadas; carta de privilégio de D. Afonso Henriques, o que leva o Procurador do Rei a desistir da demanda - Couto de São João do Monte), um referente ao processo implicando o Alcaide da Lourinhã, Rui Vasques (carta de D. Dinis), outra o Mosteiro de Pedroso (carta de privilégio), e um relativo ao processo contra Lourenço Vicente (cartas de privilégio).

Em três ocasiões é pedido pelos Procuradores que sejam analisadas as inquirições mandadas fazer por D. Dinis. Uma a pedido do Procurador do Demandado, que solicita que a sentença seja pronunciada em função das jurisdições aí provadas (Honras de Sequeiros e da Quintã do Outeiro, pertença de João Coelho), e outra a pedido do Procurador do Rei, que afirma

${ }^{43}$ Nesta fase do processo era obrigatória a presença dos dois Ouvidores, a menos que houvesse concordância de ambas as partes para que só um estivesse presente.

${ }^{44} \mathrm{O}$ que contrariava o disposto na estrutura processual do direito romano-canónico. No entanto, D. Afonso IV, num procedimento de flexibilização da orgânica processual constrangente que caracterizava este tipo de processo, e alicerçado na ideia da justa realização do direito, segundo a qual ninguém deveria ganhar ou perder um pleito por questões processuais, determina que «E esto se deue fazer sem enbargo nhuum de processo que per el nom seja nhua das partes enbargado de poeer sãs Razoões cada que as poder poeer ajnda que ante pasasse excepcoões contrairas per quallquer maneira que o fossem ou posesse algua dillatoria depois da demanda contestada. mais que todas sas Razoões sem enbargo nhuum possa poer ataa a sentença definitiua Ca mjnha emtençom he de nom seer nhua das partes enganada por processo.» (Ordenações Del-Rei..., cit., p. 322). 
desistir da demanda se tal se verificasse (Couto de Brandara, pertença de D. Chama Martins e D. Alda Martins).

Constata-se, ainda, que no decorrer de cinco processos (Mosteiro de Santa Maria de Miranda; Rui Vasques de Azevedo; Mosteiro de Cavaleiros; Mosteiro de Santa Cruz de Riba Douro; Elvira Mendes) o demandado, ou o seu Procurador por ele, não comparecem à abertura das inquirições, pelo que são julgados à revelia ${ }^{45}$, excepto no processo relativo ao couto de Miranda, do Mosteiro de Santa Maria de Miranda, em que o Procurador do Mosteiro comparece tardiamente, mas ainda a tempo, na audiência, pedindo para que lhe seja anulada a revelia, e solicitando mais tempo para apresentar as inquirições, o que é aceite pelos Ouvidores ${ }^{46}$.

Nos pleitos relativos ao Mosteiro de Sanfins de Friestas, ao Mosteiro de Santa Maria de Moreruella ${ }^{47}$ e ao Mosteiro do Bouro ${ }^{48}$, os Procuradores não apresentam as inquirições, e em quatro pleitos (Mosteiro de Almoster; Mosteiro de Refóios de Riba de Lima ${ }^{49}$; Mosteiro de Roncesvales) os Procuradores afirmam, nesta fase do processo, já não representarem a parte (neste caso o Demandado).

Sentença Interlocutória. Analisadas as inquirições, e outras possíveis provas apresentadas, os Ouvidores pronunciavam uma sentença oral.

Embargo. A sentença interlocutória era passiva da interposição de embargo suspensivo pela parte vencida, apresentando para tal um qualquer fundamento que a prejudicasse, o que acontece por dezoito vezes, sendo quatro embargos interpostos pelo Procurador do Rei, e catorze pelos Demandados, embora só num caso tenha sido considerado procedente, conduzindo à reformulação da sentença ${ }^{50}$.

${ }^{45}$ Aplicando-se o disposto numa lei de D. Afonso III, segundo a qual a parte ausente era esperada durante três dias, findos os quais se dava seguimento ao processo, sendo o faltoso julgado à revelia. (Ordenações Del-Rei..., cit., p. 97-98).

${ }^{46}$ Beneficiando, certamente, da possibilidade aberta pela citada lei de D. Afonso III que permitia que a parte em falta fosse ouvida se, embora decorridos os três dias, a carta de desembargo ainda não tivesse sido passada pela chancelaria.

${ }^{47}$ Aldeias de Montesinhos e de Quintanilha.

${ }^{48}$ Aldeias de Santa Comba, Benlhevai, Macedo do Mato, Valbom e Vilar do Monte.

${ }^{49}$ Couto de Refóios e Couto do Mosteiro de Refóios.

${ }^{50}$ Processo relativo ao Couto do Mosteiro de Refóios, pertença do Mosteiro de Refóios de Riba de Lima. 
Sentença Definitiva. A sentença definitiva era lavrada pelos dois Ouvidores, que tinham de pronunciar-se no mesmo sentido. Caso divergissem relativamente à sentença, o que se verifica no pleito envolvendo o Couto de Tarouca, pertença do Mosteiro de São João de Tarouca, tinham de reunir-se em relação os quatro Ouvidores e os dois Sobrejuízes, sendo a sentença final tomada por maioria simples, conforme disposto em lei de D. Afonso IV ${ }^{51}$.

Em caso de empate, o processo era enviado para ser decidido pelo Monarca.

Recurso. Não sendo as sentenças pronunciadas pelos dois Ouvidores passíveis de recurso de apelação ${ }^{52} \mathrm{era}$, no entanto, sempre possível dirigir ao rei um recurso de suplicação, recurso esse cuja possibilidade de interposição não decorria do exercício de um qualquer direito próprio, mas da suplicação endereçada à graça do Monarca.

Recurso de suplicação que vai ser interposto por quatro vezes, todas na década de quarenta, pelos Mosteiros de Sanfins de Friestas (Couto de Sanfins e Couto de Lusio) e de Vairão (Couto do Mosteiro de Vairão), e em duas ocasiões por Gonçalo Eanes de Briteiros (Honra de Moçães; Honra de Celarelhos, Honra de Andrães e Honra de Justes).

\section{Dos resultados do Processo}

A distribuição anual dos processos denota uma sua maior concentração nos anos de 1336 e de 1340, quase desaparecendo entre estas duas datas, e decaindo de frequência, de modo contínuo e regular, a partir desta última.

Sendo o elevado número de processos dirimidos em 1336 explicitável por se estar em data próxima à do início do Chamamento Geral (ainda assim dois a três anos depois do édito que o iniciou, o que mostra as dificuldades inerentes à sua concretização e, porventura, o lento e prolongado desenrolar dos pleitos), a sua quase inexistência nos anos de 1337, 1338 e 1339 também se compreende facilmente, se tivermos em conta que a guerra com Castela terá, necessariamente, feito concentrar os propósitos régios nesse conflito,

\footnotetext{
${ }^{51}$ Ordenações Del-Rei..., cit., p. 325.

${ }^{52}$ Ordenações Del-Rei..., cit., p. 324.
} 
N. ${ }^{o}$ de Processo por Ano

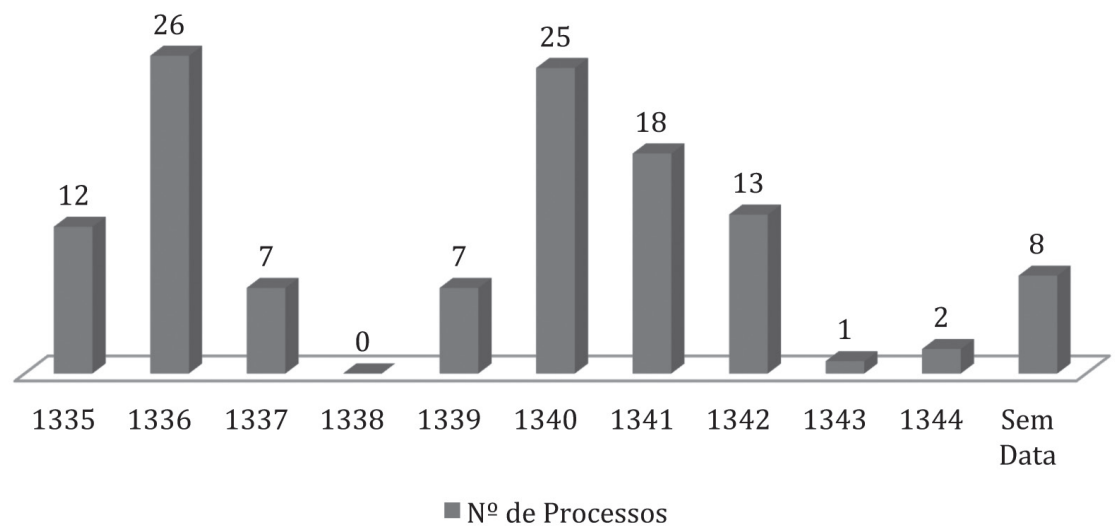

deixando para segundo plano a sua luta jurisdicional, por maioria de razão quando esta implicaria a emergência de diferendos fraturantes com aqueles que eram imprescindíveis à sustentação de tal empreendimento bélico.

Passado o conflito seria, então, possível retomar a tentativa de concretização dos objectivos que tinham ditado a promulgação do citado Édito, circunstâncias essas que explicariam o exponencial aumento de processos despachados no ano de 1340 .

Tendo em conta o elevado número de pleitos sentenciados neste ano, parece improcedente a conjectura de José Marques ${ }^{53}$, que atribui importância decisiva, no desenrolar do Chamamento Geral, ao êxito obtido na Batalha do Salado.

Menos compreensível é o reduzidíssimo número de sentenças pronunciadas no ano de 1344, numa altura em que a Nobreza, em troca da sua comparência a juízo, procurava obter do Monarca condições mais vantajosas relativamente à determinação do direito de exercício das jurisdições que reclamava como suas.

Jurisdições, cível e ou crime, cujo uso era reclamado pelos Senhores em $84 \%$ das terras imunes que foram a julgamento, o que mostra que, embora o exercício de jurisdição cível e ou crime não fosse correlativo à posse de

${ }^{53}$ MARQUES, José - D. Afonso IV..., cit. 
uma Honra ou Couto, essa correlação se verificava na maior parte dos casos, principalmente no que se refere ao direito cível, cujo exercício nas suas terras era afirmado, também, em $84 \%$ das situações, enquanto que no que se refere à jurisdição criminal o mesmo só acontecia num número muito residual de alegações: $36 \%$.

A afirmação do Rei como Juiz, e do poder régio como um poder que assenta, primordialmente, no dever de julgar, como forma de manter a paz no Reino e, deste modo, contribuir para a concretização do bem comum, um dos deveres maiores que o oficio régio lhe impunha, pode permitir aventar a hipótese de que os Reis portugueses tenham, desde muito cedo, assumido para si próprios, e em quase exclusividade, o direito de julgar os feitos criminais, o que explicaria a pouca relevância numérica da jurisdição criminal no cômputo dos poderes exercidos pelos senhores, na medida em que são, precisamente, os feitos crime aqueles que mais colocam em perigo a ordem e concordância que devem pautar a vida da comunidade, razão pela qual alguns deles serão mesmo declarados crimes públicos, podendo a querela iniciar-se, por inquirição devassa, sem qualquer queixa apresentada pela vítima.

Sendo os ilícitos criminais aqueles que de forma mais pregnante põem em causa a manutenção do bem comum e da paz na globalidade do Reino, na medida em que não só atentam contra os direitos fundamentais daqueles que nele habitam, como perturbam, e podem chegar a dissolver, a ordem que deve existir, e perdurar, no todo social, podem ser considerados como relevando de direito de carácter público e, portanto, dependente, de um modo essencial, do supremo poder do Reino. Já os ilícitos civis, por sua vez, estão mais ligados aos interesses particulares dos indivíduos tomados isoladamente, não pondo em causa, de um modo determinante, a coesão e ordenação da comunidade, e relevando do direito privado.

Percebe-se, portanto, que os Reis, no exercício do seu poder jurisdicional, e enquanto mantenedores da paz e aplicadores do direito, começassem por tentar assumir na sua plenitude o julgamento dos casos de direito público, abdicando da mesma plenitude no que se refere aos casos de direito privado, permitindo, deste modo, que os Senhores o exercessem mais intensamente.

A diferença de intensidade verificada entre a proclamação do exercício dos poderes judiciais de tipo cível e criminal, por parte das Instituições 
demandadas, pode, assim, ser pensada em função de uma estratégia régia de afirmação daquilo que era considerado como o fundamento essencial do seu poder, ao mesmo tempo que contribuía para a consolidação de uma determinada teoria do poder régio, cujos contornos foram anteriormente delineados ${ }^{54}$.

Não se pode, no entanto, dizer que a vitória do Monarca tenha sido absoluta e avassaladora, na medida em que ganha totalmente apenas $42 \%$ dos processos instaurados. Nem outra coisa, aliás, deveria estar na mente de D. Afonso IV. Não se tratava, certamente, de afrontar directa e abertamente o poder senhorial, privando os Senhores de todas as suas prerrogativas, mas de tentar contê-lo dentro de limites razoáveis, impedindo que ele alastrasse, e afirmando, no mesmo movimento, a absoluta superioridade do poder real, enquanto possuidor fundacional de todo o poderio no Reino, que os outros apenas usariam em função de uma mercê régia, num desdobramento teórico alicerçado nos princípios decorrentes da imposição, e expansão, do direito romano, enquanto interpretado por glosadores e comentadores ${ }^{55}$.

Devido a esse desejo de não afrontar aberta e declaradamente a ordem Senhorial, por um lado e, por outro, para manifestar a justiça no exercício do poder, a que o seu ofício o obrigava, não seria lícito, à partida, pensar na hipótese de uma manipulação declarada dos processos, por parte das justiças régias. Os próprios resultados do empreendimento o parecem confirmar. Mas, mais decisivo ainda quanto a esta questão, é a forma como decorreram os processos judiciais, a partir da análise dos quais se torna manifesto que as sentenças terão sido dadas em função dos factos provados.

${ }^{54}$ Rei-Juiz, detentor de um poder fundacional, condição de legitimidade de todos os outros poderes exercidos no Reino.

${ }^{55}$ Fica-se por esta breve expressão, na medida em que não cabe aqui uma análise dos modos de aplicação do direito romano, cujas modalidades de desdobramento são determinadas por uma estrutura anfibológica e por um elevado grau de complexidade, mas que não pode, de modo algum, ser analisada em termos de influência, pois mais que ponto de partida ele se configura enquanto ponto de chegada, dispositivo legitimatório. Como afirma Paolo Grossi «Gli uomini del diritto comune sono soltanto formalmente dei romanisti, mentre il testo romano è ben spesso solo la copertura autoritativa (...) di una costruzione giuridica che si sviluppa autonoma e che trova la propria fonte sostanziale (...) nella incandescenza dei novissimi fatti economici e social della civiltà medievale.» GROSSI, Paolo - L'Ordine..., cit., p. 11. 
O rei parece, portanto, ter sabido manter-se fiel ao exercício ponderado da justiça. O que não invalida que o panorama jurisdicional do Reino se tenha visto substancialmente alterado após todo este processo iniciado com o Édito de 1333/1334. Alteração visível na passagem do número de Coutos e Honras, em que os Senhores exerciam um qualquer tipo de poder jurisdicional, de $84 \%$ para $44 \%$ do total das terras imunes que foram sujeitas a pleito, modificação particularmente significativa no que concerne à possibilidade de julgar feitos crime, que passa de $36 \%$ para uns insignificantes $9 \%$.

Verifica-se, assim, que o procedimento levado a cabo por D. Afonso IV implicou, inequivocamente, uma apropriação, por parte do Rei, de poderes que até então lhe escapavam, contribuindo, decerto, para uma afirmação do seu poder, e para uma diminuição do poder dos Senhores.

Embora não constituindo um corte radical com a gestão dos poderes até então vigente no território português, o Chamamento Geral protagonizado por D. Afonso IV institui-se como uma afirmação categórica do carácter outro do poder do Monarca, relativamente aos restantes poderes em exercício no espaço do Reino, assumindo-se como verdadeiro ato de propaganda da soberania régia, e dando a ver, senão o poder que já detinha, pelo menos o poder que afirmava deter.

De qualquer modo, este processo não teve um mero efeito propagandístico e simbólico, na medida em que conduziu a uma apropriação, pelo Rei, de poderes e direitos exercidos até então pelos Senhores do Reino, mas, acima de tudo, levou à afirmação inequívoca do seu poder. Afirmação que se entrevê no pedido dos Fidalgos para que o Soberano lhes faça mercê de poderem continuar a usar das jurisdições e direitos nas suas terras tal como o faziam ao tempo das inquirições mandadas realizar por D. Dinis.

Asserção de absoluta superioridade do poder do Monarca relativamente a todos os outros que, no entanto, não terá impedido o Rei de se manter fiel a uma Justiça que apregoava como sendo o fundamento último do exercício do seu ministério, e que, no mesmo movimento, se instituía como dispositivo legitimatório do seu poder.

Deste modo, o que está em causa, mais que uma tentativa de centralização do poder, é a afirmação inequívoca do poderio do Monarca, através da materialização de uma adequação pura entre os princípios constituintes do oficio régio e a prática efetiva que o Rei vai desdobrando. 


\begin{tabular}{|c|c|c|c|c|c|c|c|c|c|c|c|c|c|c|c|c|c|c|c|c|c|c|c|c|}
\hline \multirow{3}{*}{ 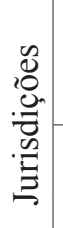 } & $\mathscr{\Xi}$ & ค & 1 & 1 & 1 & 1 & 1 & 1 & 1 & 1 & 1 & 1 & $x$ & 1 & ' & $*$ & 1 & ' & 1 & ' & ' & ' & ' & 1 \\
\hline & $\mathcal{U}$ & $\varangle$ & $x$ & ' & ' & ' & ' & 1 & 1 & 1 & 1 & 1 & $x$ & ' & I & $x$ & ' & ' & ' & ' & 1 & ' & I & 1 \\
\hline & $\overline{8}$ & ค & $x$ & ' & $*$ & $x$ & $x$ & $x$ & $x$ & $x$ & $x$ & $x$ & $x$ & $x$ & $*$ & * & $x$ & $x$ & $x$ & $x$ & ' & $x$ & $*$ & $x$ \\
\hline & & $\varangle$ & $x$ & $x$ & $x$ & $x$ & $x$ & $x$ & $x$ & $x$ & $x$ & $x$ & $x$ & $x$ & $\measuredangle$ & $x$ & $x$ & $x$ & $x$ & $x$ & $x$ & $<$ & $x$ & $x$ \\
\hline
\end{tabular}

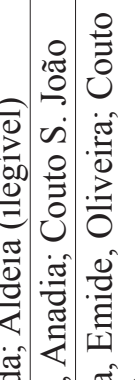

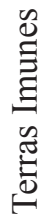

:

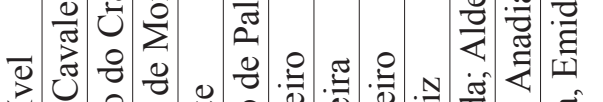

胥

苐

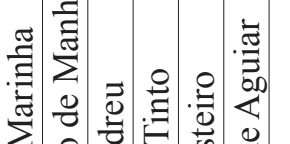

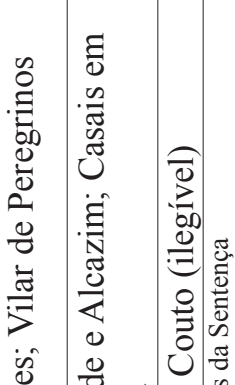

.00

荥

.ᄏ

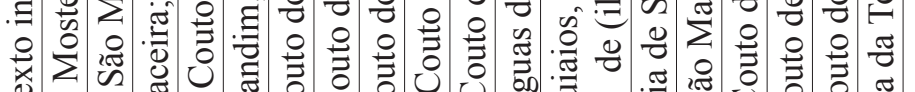

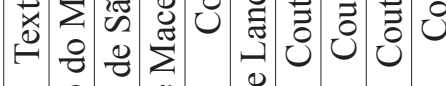

\begin{tabular}{cc|c|c|}
0 & 0 & 0 & 0 \\
0 & 0 & 0 & 0 \\
0 & 0 & 0 \\
0 & 0 & 0 \\
0 & 0 & 0 \\
& 0 & 0
\end{tabular}

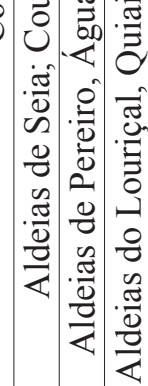

$\approx \sim \frac{0}{2}$

䓪

$$
\text { (3) }
$$

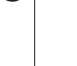

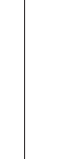

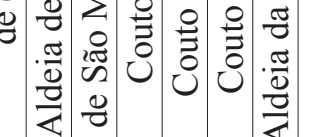

过

要

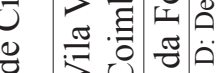

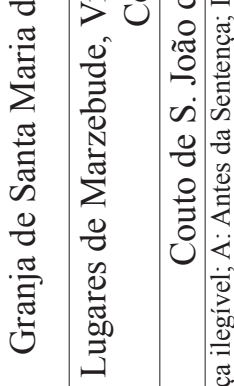

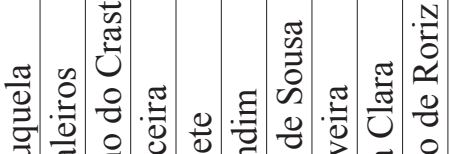

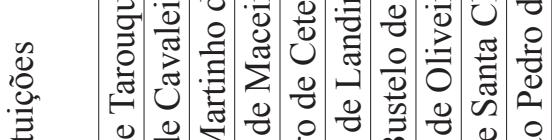

晃

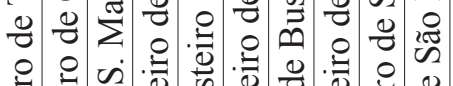

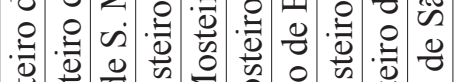

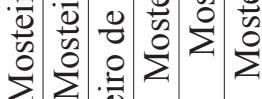

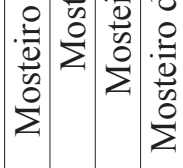

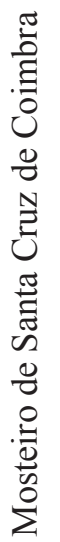

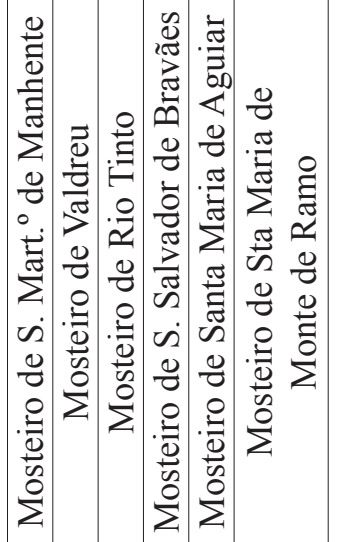

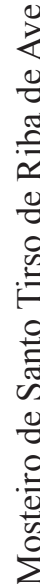




\begin{tabular}{|c|c|c|c|c|c|c|c|c|c|c|c|c|c|c|c|c|c|c|c|c|}
\hline \multirow{4}{*}{ 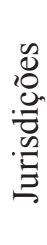 } & \multirow{2}{*}{ 苞 } & 0 & 1 & 1 & 1 & 1 & I & ' & 1 & 1 & 1 & 1 & 1 & 1 & I & $x$ & 1 & 1 & 1 & \\
\hline & & $\varangle$ & 1 & 1 & 1 & 1 & 1 & $x$ & 1 & 1 & 1 & 1 & 1 & 1 & 1 & $x x$ & 1 & I & $x$ & \\
\hline & $\bar{\nabla}$ & ค & $x$ & 1 & $x$ & $x$ & I & $x$ & 1 & $x$ & 1 & 1 & 1 & $x$ & I & $x$ & 1 & I & 1 & \\
\hline & 5 & $\varangle$ & $x$ & $x$ & $x$ & $x$ & $x$ & $x$ & $x$ & $x$ & $x$ & $x$ & $x$ & $x$ & $x$ & $x \times$ & $x$ & $x$ & $x$ & \\
\hline & 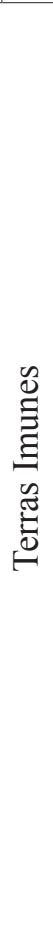 & & 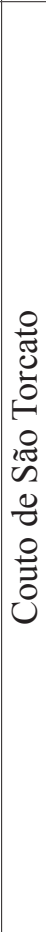 & 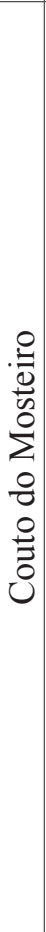 & 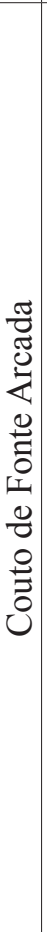 & 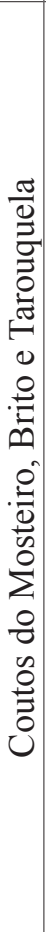 & 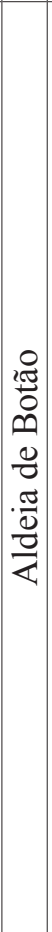 & 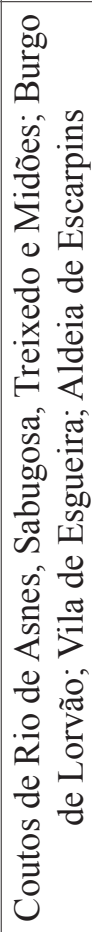 & 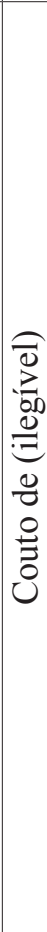 & 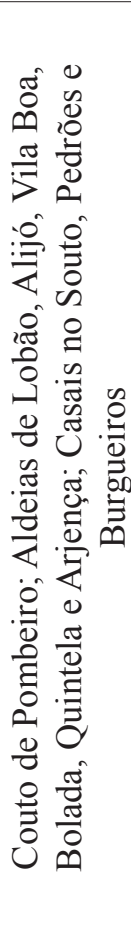 & 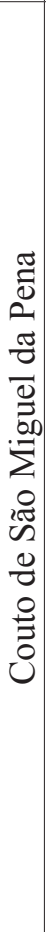 & 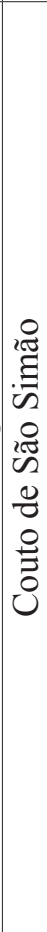 & 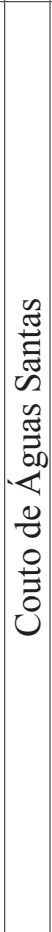 & $\mid \begin{array}{l}0 \\
\Xi \\
0 \\
0 \\
0 \\
0 \\
0 \\
0 \\
0 \\
0 \\
ن\end{array}$ & 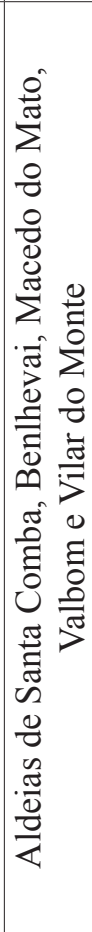 & 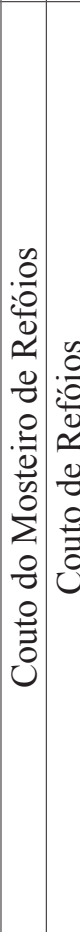 & 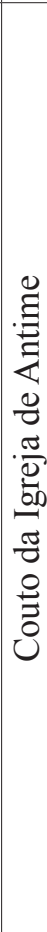 & 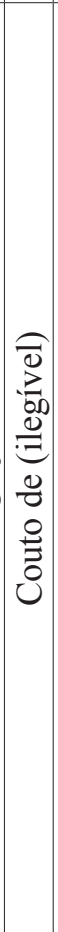 & 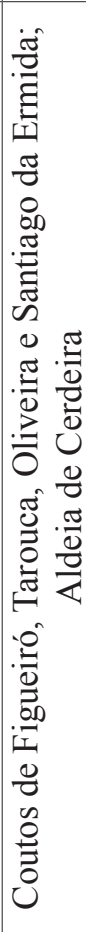 & 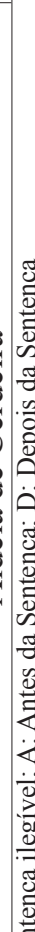 \\
\hline & 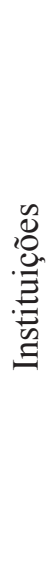 & & 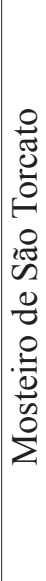 & 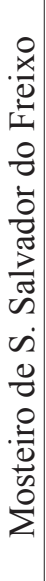 & 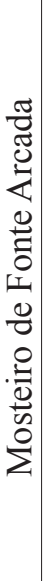 & 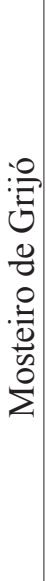 & & 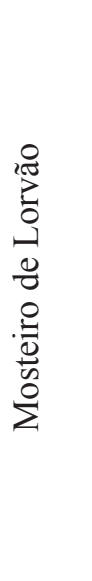 & 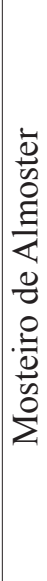 & 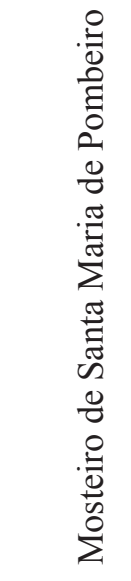 & & 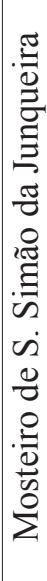 & 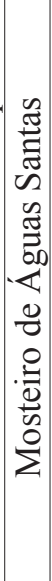 & & $\begin{array}{l}0 \\
0 \\
0 \\
0 \\
0 \\
0 \\
0 \\
.0 \\
\stackrel{0}{0} \\
0 \\
0\end{array}$ & 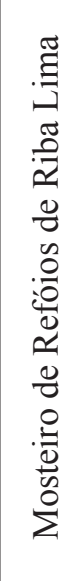 & 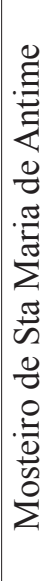 & 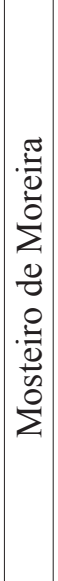 & 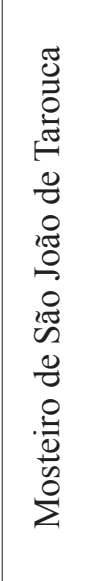 & 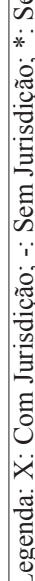 \\
\hline
\end{tabular}




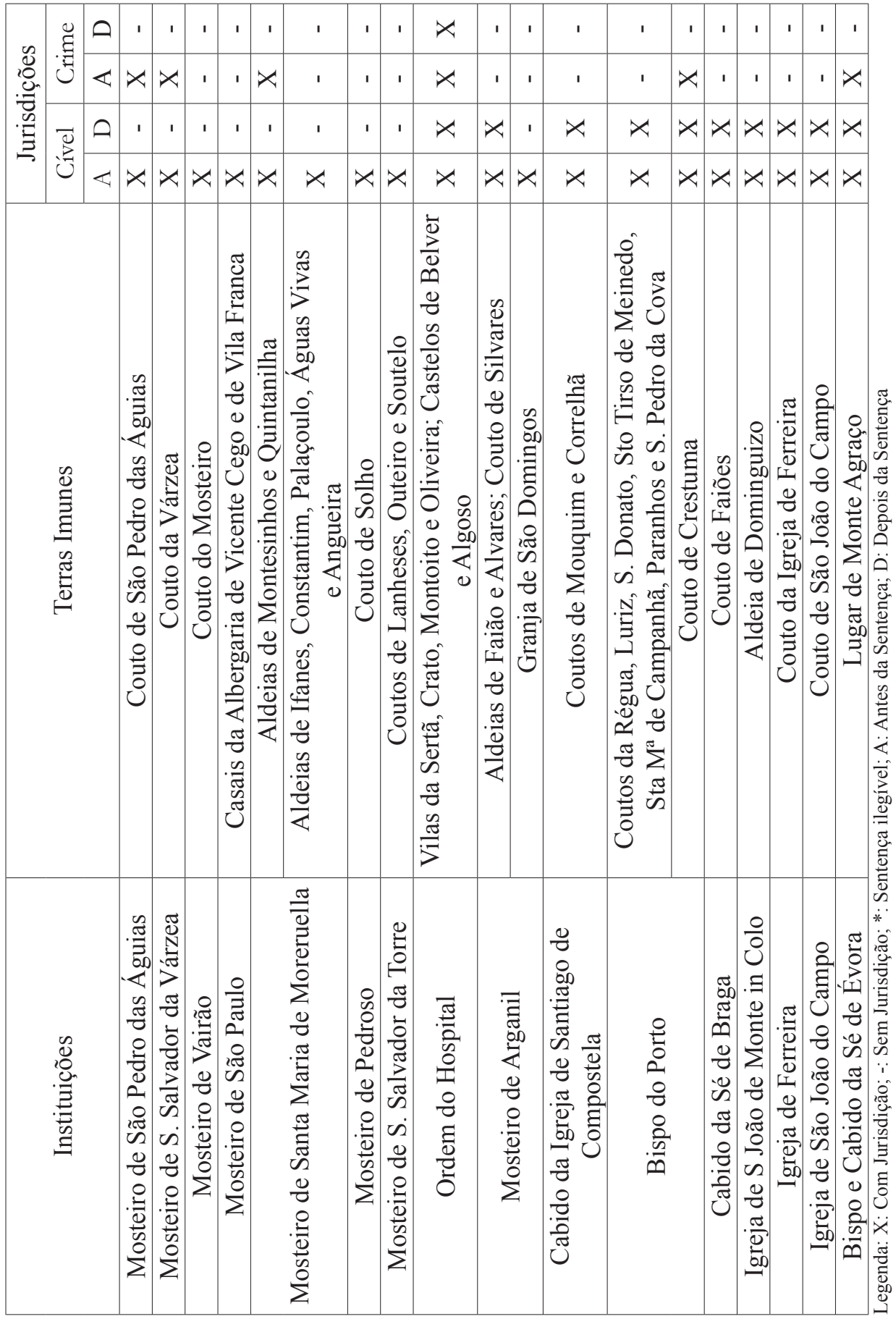




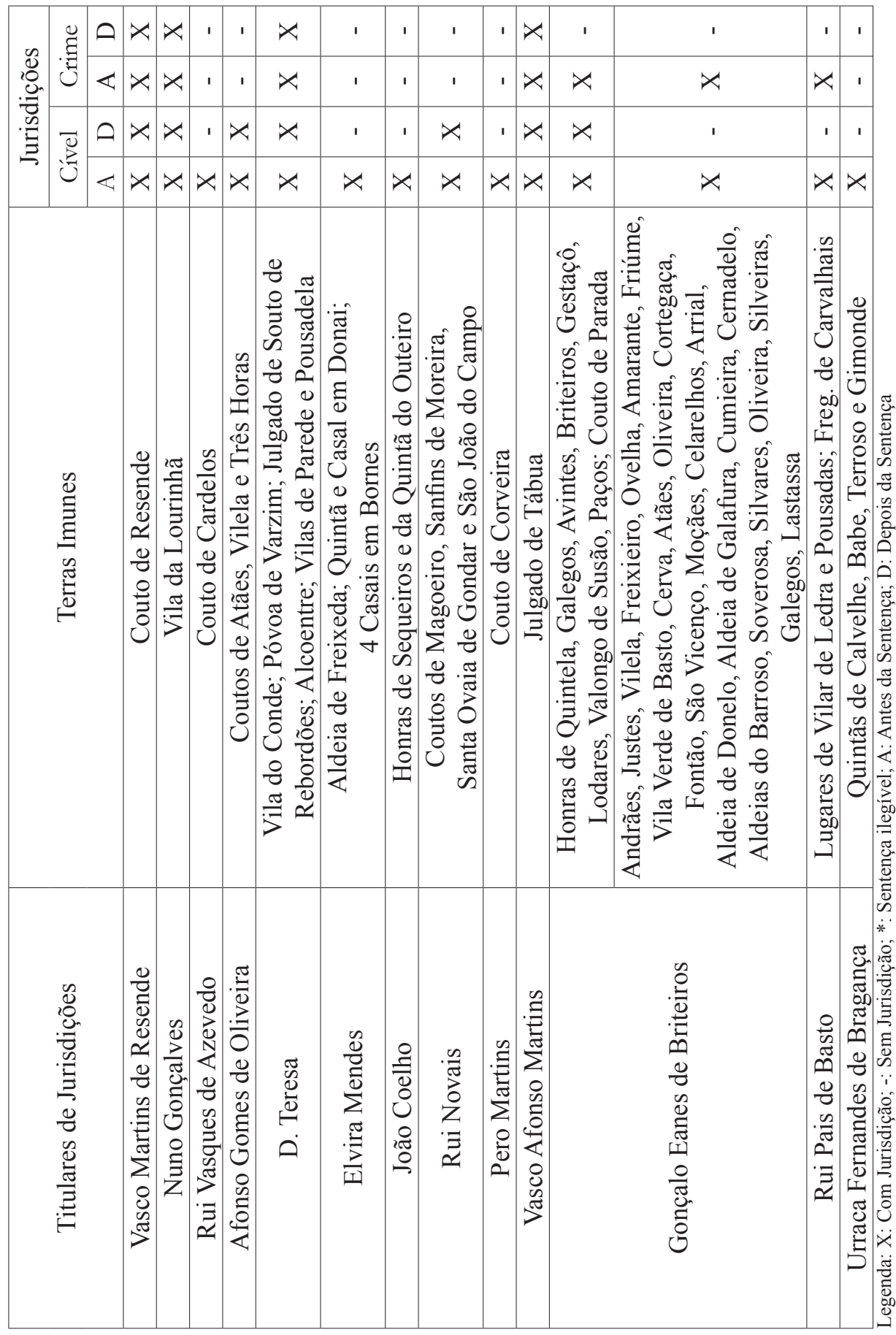

